\title{
LIETUVOS KAIMO GYVENAMŲJŲ VIETOVIŲ POKYČIŲ TYRIMAI
}

\author{
Pranas Aleknavičius ${ }^{a}$, Marius Aleknavičius ${ }^{b}$, Sigita Akelaitytè \\ Aleksandro Stulginskio universitetas, Žemètvarkos ir geomatikos institutas, \\ Universiteto g. 10, LT-53361 Kaunas-Akademija, Lietuva \\ El.paštas: appranas.aleknavicius@gmail.com (korespondencijos autorius); \\ bamarius@takas.lt; csigitakela@yahoo.com \\ Itteikta 201402 04; priimta 20140415
}

\begin{abstract}
Santrauka. Straipsnyje pateikiama gyventojų surašymo statistinių duomenų analizė pagal savivaldybes ir kaimo gyvenamąsias vietoves, taip pat savivaldybių teritorijų bendrųjų planų analizè. Nustatyta žemės ūkio dirbančiųjų ir gyvulius laikančių šeimų skaičiaus mažèjimo įtaka kaimo gyventojų ir žemés ūkio veiklos subjektų ūkių išsidèstymo tankumui. Analizuojamos stambiosios kaimo gyvenvietès sugrupuotos pagal jų dislokaciją i priemiestines bei atskirai išsidèsčiusias gyvenvietes, tarp jų miestelius ir buvusias žemės ūkio įmonių centrines gyvenvietes, nustatyta jų pokyčių dinamika. Išnagrinètos galimybės reguliuoti kaimo gyvenamụjų vietovių plètrą rengiant savivaldybių teritorijų bendruosius planus - parinkti vystymui perspektyvius lokalinius centrus, reikalingus šeimoms ir ūkiniams subjektams aptarnauti agrarinèse bei kitose aplinkinèse vietovèse. Tai padètų išsaugoti našias žemès ūkio naudmenas ir intensyvinti tradicinę žemès ūkio veiklą, ypač probleminiuose rajonuose, kuriuose yra sparčiai nykstančių kaimų.
\end{abstract}

Reikšminiai žodžiai: gyvenamosios vietovès, žemės ūkio paskirties žemė, miestelis, kaimas, bendrieji planai.

Nuoroda į šs̆ straipsnį: Aleknavičius, P.; Aleknavičius, M.; Akelaityte, S. 2014. Lietuvos kaimo gyvenamųjų vietovių pokyčių tyrimai, Journal of Architecture and Urbanism 38(2): 161-172.

\section{Ivadas}

Spartus Lietuvos gyventojų skaičiaus mažejimas yra viena iš priežasčių, kad atskiros šalies teritorijos dalys vystosi netolygiai. Tai turi itakos ir racionaliam ariamosios žemès bei kitų gamtos išteklių naudojimui bei žemès ūkio gamybos intensyvumui. Šie procesai nagrinètini ir vertintini atsižvelgiant ị žemès administravimo politiką formuojančių tarptautinių bei Lietuvos programinių dokumentų nuostatas. Pavyzdžiui, Torremolinos chartijoje, nustačiusioje teritorijų planavimo principus bei tikslus, nurodyta, jog „labai svarbu sukurti priimtinas gyvenimo sąlygas kaime, kalbant apie visus ekonominius, socialinius, kultūrinius ir aplinkosaugos aspektus, taip pat infrastruktūrą ir patogumus, o atskirti pagal išsivysčiusias ir periferines bei arti didmiesčių esančias kaimo vietoves" (European... 1983). Europos kaimiškųjų sričių chartijoje pažymèta, jog būtina išvengti prasidejusių neigiamų tendencijų - kaimo gyventojų skaičiaus mažejimo ir tradicinio ūkininkavimo būdo praradimo. Siūlomos priemonès: jaunųjų ūkininkų rèmimas, verslo, amatininkystès ir kaimo turizmo skatinimas, gyvenamųjų namų statyba, šiuolaikinès transporto ir ryšių sistemos plètojimas, kultūriniam kaimiškajam kraštovaizdžiui formuoti ir apsaugoti palanki ūkinè veikla (European... 1996). 1996 m. priimtoje „Stambulo deklaracijoje dèl gyvenviečių“ (Stambulo... 1996) teigiama, kad kaimo ir miesto pletra tarpusavyje yra susijusi. Deklaracijoje nurodoma, kad, gerinant gyvenimo sąlygas miestuose, privalu plètoti ir kaimo infrastruktūrą, viešąsias paslaugas, didinti užimtumo galimybes ir kitaip didinti kaimo regionų patrauklumą. Būtina plètoti kompleksinį gyvenviečių tinklą ir kiek ¿̇manoma mažinti migraciją iš kaimo ị miestą. Lietuvos Respublikos teritorijos bendrajame plane (Lietuvos... 2002) nurodyta, jog vienas iš Lietuvos teritorijos raidos strateginių tikslų yra: „siekti racionalios ir tikslingos gyventojų koncentracijos ir depopuliacijos tendencijų pusiausvyros stiprinant silpnąsias gyvenamųjų vietovių tinklo grandis“. 
Kaimo gyventojų skaičius Lietuvoje sparčiausiai mažéjo XX a. antrojoje puseje dèl suaktyvejjusios urbanizacijos (didžiųjų miestų augimo), nuosavybès teisių į žemę praradimo, sąlygos gyventi ir dirbti kaime tapo ne tokios palankios lyginant su kitomis ūkinès veiklos sritimis, taip pat sumažèjo gimstamumas (Aleknavičius 2007). Dar viena priežastis - gyventoju persikèlimą į miestus XX a. antrojoje puseje lèmé spartus pramonès augimas. Miestu vystymasis turëjo ittakos esminèms visuomenès švietimo, profesinès struktūros, būsto ir net kasdieninès buitinès elgsenos permainoms. Šiuo metu didžioji dalis dabartinių miesto gyventojų prieš tris ar daugiau dešimtmečių iš kaimo gyvenamųjų vietovių atvykę asmenys ir dabartiniai jų palikuonys (Jasaitis, Šurkuvienė 2006). G. Kuliešis ir L. Pareigienè (2011) nurodo, kad per pastaruosius du dešimtmečius gyventojų kaitą būtų galima apibūdinti kaip depopuliaciją, nes gyventojų skaičius nuolat mažějo visoje šalyje, išskyrus sostinę Vilnių. E. Kriaučiūnas ir G. Ribokas (2012) pabrèžia, kad atokesnèse teritorijose, kuriose žemès ir miškų ūkis neturi veiklos alternatyvų, kaimo gyventojų skaičius intensyviai mažèja. Formuojasi retai gyvenamų teritorijų arealai; anksčiau tai buvo būdinga Rytu Lietuvai, pastaraisiais metais kaimo teritorijos itin sparčiai retejja ir kituose regionuose. Aleknavičius (2007) teigia, kad nesant gyventojų žemė dirvonuoja ir palaipsniui tampa netinkama naudoti be papildomu melioracinių priemonių. Dèl tolesnio kaimo gyventojų skaičiaus mažèjimo gali būti apleidžiami ar ekstensyviai naudojami derlingų dirbamųjų žemių plotai ir išnykti kaimai. Tačiau kaimo gyventojų pokyčiai sietini ir su žemès naudojimo žemès ūkiui intensyvumu. Teritorijose, kurioms būdingi potencialiai derlingiausi dirvožemiai, yra didesnis žemès ūkio naudmenų procentas, daugiausia dèl melioracijos darbų sukultūrintų žemių, gaunama daugiau pajamų.

Nagrinèdamas kaimo gyvenviečių raidos pokyčius E. Kriaučiūnas (2013) teigia, kad jie vyksta chaotiškai, o gyvenvietèse vykstantiems demografiniams, socialiniams ir ekonominiams procesams valstybès ir savivaldybių institucijų įtaka nèra labai didelè. Akivaizdu, kad trūksta ne tik finansinių išteklių, bet ir vieno bendrojo valstybinio požiūrio ị kaimo gyvenviečių ateitį. L. Dringelis (2013) nurodo, kad besikeičianti demografinè situacija, kuri yra susijusi su Lietuvos ekonomine būkle, yra svarbus veiksnys, lemiantis urbanistinius pokyčius - miestų, miestelių ir kaimų mažejimą bei nykimą. Tai užburtas ratas, kurị sudaro minètų veiksnių - ekonomikos, demografijos ir urbanistikos - koreliacija. Vidickienè ir Melnikienè (2008) nurodo, kad laikui bėgant regionų konkurencingumas vis labiau priklausys nuo to, kiek jie gali pritraukti žmogiškuju išteklių. Dèl šios priežasties prastesneje padètyje atsidurs kaimo teritorijos, nes aktyvejjantys vidinès migracijos procesai šalyje ir vykstanti tam tikrų teritorijų depopuliacija blogina ekonominę ir socialinę aplinką, mažina regionų potencialą bei konkurencingumą. Kaimo regionai turi konkuruoti dèl investicijų ir kvalifikuotos darbo jègos su kitomis Europos Sąjungos šalimis ir Lietuvos miestais.

Anglijoje, JAV, Švedijoje ir Australijoje buvo atlikti tyrimai, kurių metu nustatyta, kad trečdalio migruojančiųjų šalies viduje pagrindinis motyvas yra užimtumas ir ịsidarbinimo galimybès. Likusieji asmenys gyvenamąją vietą keičia dèl kitų priežasčių (Morrison, Clark 2011; Niedomysl 2006). Taigi žmonių migracijai itakos turi ir jų asmeniniai poreikiai bei aplinka.

Pasak Jasaičio ir Šurkuvienès (2006), svarbiausiu prioritetu šiuolaikinio strateginio valdymo procese turètų būti visų regionų darnios plètros igyvendinimas. Jasaitis (2008) nurodo, kad būtina atkurti kaimo vietovių buitinio aptarnavimo sistemą ir sustabdyti kaimo socialinès atskirties didejjimą. Atkočiūnienè ir Giedraitis (2013) teigia, kad ypač svarbu stiprinti kaimo vietovių gyvybingumą, didinti gyventojų užimtumą ir pajamų stabilumą.

Lietuvos Respublikos teritorijos bendrajame plane (Lietuvos... 2002) nurodoma, kad plètojant miesto ir kaimo teritorijų ryšius būtina atkurti gyvenamųjų vietovių sistemas naujomis socialinemis ir ekonominèmis sąlygomis. Svarbi grandis būtų seniūnijų centrų, t. y. mažų miestų ir miestelių, kaip žemès ūkio gamybos ir kaimo gyventojų aptarnavimo, iš dalies miesto gyventojų rekreacijos centrų, plètojimas. Šiuos klausimus nagrineję autoriai siūlo geriau integruoti miestus ir regionus, sudaryti sąlygas darniam mažų ir vidutinio dydžio miestų tinklui, išvengiant miestų driekos ir kaimo gyvenamųjų vietovių depopuliacijos (Čereškevičius 2012). XXI amžiuje Lietuvos miesteliai turi būti plètojami siekiant užstatymo kompaktiškumo, darnos ir gyvenimo kokybès. Jų išsidèstymas šalies ar regiono teritorijose turètų būti kiek ịmanoma tolygesnis, o aprūpinimas visapusiška infrastruktūra turetų mažinti skirtumus tarp kaimo ir miesto (Burinskienè, Lazauskaitè 2010). Lietuvos kaimo gyvenamosios vietovès turi būti vystomos vadovaujantis bendraisiais teritorijų planavimo dokumentais, parengtais atlikus išsamią vykstančiu procesų analizę. Kaip pažymi Baležentis (2011), kaimo vietovių vertinimas darnaus vystymo požiūriu gali būti taikomas formuojant kaimo vystymo politiką ir rengiant strateginius dokumentus. Bendrasis planavimas turi tapti integralia socialine, ekonomine ir aplinkosaugos priemone. Būtina pasiekti, kad plètra būtų susieta su adekvačiu socialinès ir inžinerinès infrastruktūros vystymu (Pakalnis, Bardauskienè 2012). 
Formuojant gyvenamųjų vietovių vystymo politiką, rengiant, priimant ir igyvendinant kaimo vietovių pokyčių valdymo spendimus, būtina remtis strateginèmis ịžvalgomis, orientuotomis ị ilgalaikę perspektyvą (Atkočiūnienė, Vaišnoraitė 2012). Kaip rodo kitose šalyse atlikti tyrimai, padidinus investicijas ị žemès ūkį, ju sukuriama vertè yra didesnè nei vien tik iš žemès ùkio produkcijos gaunamos pajamos, nes kaimuose buvo sukurtos sąlygos, tinkamos vystytis kitoms sritims, tokioms kaip kultūra ar švietimas, ir tai padidino šių kaimų plètros strategines galimybes.

Europos Bendrijų statistikos tarnyba prognozuoja, kad 2060 m. pradžioje Lietuvoje gyvens ketvirtadaliu mažiau gyventojų negu dabar. Tarp Europos Sąjungos šalių Lietuvą depopuliacijos tempu lenkia tik Latvija ir Bulgarija (Kasnauskienè ir kt. 2009). Taigi, ịvertinant tai, kad gyventojai pastaraisiais metais turi tendenciją koncentruotis miestuose, reikètų didesnị dèmesị skirti kaimo gyvenviečių plètrai ir vystymuisi.

Siekiant reguliuoti kaimo plètros procesus, būtinos priemonès - teritorijų planavimo dokumentai, ekonominè tikslinè parama ir žemès naudojimą bei teritorijų tvarkymą reglamentuojančiu norminių teisès aktų tobulinimas (Aleknavičius 2007). Šiame straipsnyje atliktų tyrimų tikslas - išnagrinèti kaimo apgyvendinimo sistemos pokyčius Lietuvos savivaldybèse ir gyvenviečių plètrai reguliuoti taikomas priemones. Tikslui pasiekti keliami uždaviniai:

- išanalizuoti gyventojų ir žemès ūkio veiklos subjektų ūkių išdèstymo tankumą bei jo pokyčius;

- nustatyti kaimo gyvenamųjų vietovių struktūrą pagal jų dydį ir išsidèstymą bei kitimo tendencijas;

- išnagrinèti galimybę planingai reguliuoti stambiụjų kaimo gyvenviečių plètrą rengiant savivaldybių teritorijų bendruosius planus.

\section{Tyrimo metodika}

Tyrimų tikslui ir keliamiems uždaviniams pasiekti buvo taikomi informacijos paieškos, sisteminimo, kartografinès medžiagos analizès, statistinių duomenų analizès, mokslinès literatūros analizès, lyginamosios analizės ir apibendrinimo metodai. Tyrimams panaudoti strateginiai ir teritorijų planavimo dokumentai, Statistikos departamento duomenys apie gyventojų surašymo rodiklius. Gyvenamųjų vietovių klasifikacinè analizè atlikta panaudojus valstybès įmonès Valstybès žemès fondas žemèlapius su kartografuotais objektais - miestu ir kaimu ribomis, išdèstytomis urbanizuotomis teritorijomis ir vienkiemiais. Savivaldybiu teritoriju bendruju planų analizei panaudoti ju aprašomoji (tekstinè) dalis bei brèžiniai (grafinè dalis), skel- biami internete. Statistinių duomenų analizei panaudotos kompiuterinès programos, taikyti matematiniai statistiniai metodai.

\section{Tyrimo rezultatai}

\section{Kaimo gyvenamuju vietoviu išsidestymas ir jam įtakos turintys veiksniai}

Kaimo gyvenamųjų vietovių išsidèstymas Lietuvoje vyko istoriškai, łgyjant žemę nuosavybės ar valdymo teise. Dažniausiai šie procesai susiję su ūkininkavimu, naudojant žemę žemès ūkio produkcijai auginti. Todèl pagrindiniu kaimo apgyvendinimo sistemos tankumo rodikliu (Y) tyrimuose pasirinktas ūkių skaičius, tenkantis 100 ha žemès ūkio paskirties žemès. Ūkiu laikomas žemès ūkio veiklos subjekto valdomas teritorinis vienetas, naudojantis (pagal Visuotinio žemès ūkio surašymo duomenis) ne mažiau kaip 1 ha žemès ūkio naudmenų. Siekiant nustatyti priežastis, dèl kurių gyventojų tankumas atskirose administracinèse teritorijose (savivaldybėse) yra skirtingas ir jo pokyčiai vyksta nevienodu intensyvumu, išnagrinèta:

1) ùkių tankumo priklausomybè nuo kaimo gyventojų tankumo - ploto vienetui (100 ha žemès ūkio paskirties žemès) tenkančio kaimo gyventoju skaičiaus, buvusio $2001 \mathrm{~m}$. gyventoju surašymo metu. Šis rodiklis yra santykinai stabilus ir gali parodyti ilgalaikio kaimo apgyvendinimo sistemos formavimosi pasekmių įtaką ūkių tankumui. Kaip matyti iš 1 pav., tankiausiai apgyvendinti Vilniaus ir Kauno rajonai (70,4-74,4 gyv./100 ha). Didesnis kaimo gyventojų tankumas yra Pietų Lietuvoje (30,9-48,0 gyv./100 ha), mažiausias tankumas - Šiaurès ir Šiaurès Rytų Lietuvoje (17,9-24,9 gyv./100 ha);

2) ūkių tankumo priklausomybè nuo žemès ūkio veiklos pokyčių intensyvumo per laikotarpi tarp Visuotinio žemès ūkio surašymo metų $-2003 \mathrm{~m}$. ir $2010 \mathrm{~m}$. Žemès ūkio veiklai apibūdinti pasirinkti rodikliai, kurie susiję su ūkininkavimu: žemès ūkyje užimtų darbuotojų skaičius, šeimų, laikančių galvijus, skaičius ir šeimų, laikančių kiaules, skaičius. Iš viso Lietuvoje per minètą 7 metų laikotarpi žemès ūkyje užimtų darbuotojų skaičius sumažèjo nuo 545381 iki 369033 (36,3\%), galvijus laikančių ūkių skaičius - nuo 210054 iki 101590 (51,6 \%), kiaules laikančių ūkių skaičius - nuo 169172 iki $68103(59,7 \%)$.

Siekiant eliminuoti stambiụų miestų itaką tyrimu rezultatams, ị skaičiavimus neįtraukti priemiestiniai Vilniaus, Kauno ir Klaipeddos rajonai. 
Regresinè porinès koreliacijos priklausomybès analizė parodè vidutinio ir pastebimo stiprumo ryšio glaudumą tarp šių rodiklių:

1. Ükių tankumo (Y) ir kaimo gyventojų tankumo $\left(\mathbf{X}_{1}, 2\right.$ pav.).
2. Ūkių tankumo (Y) ir žemės ūkio veikla užsiimančių darbuotojų skaičiaus pokyčių per 2003-2010 m. laikotarpi $\left(\mathbf{X}_{2}\right)$ : ploto vienetui tenkantis ūkių skaičius didesnis tose savivaldybèse, kuriose lèčiau mažèjo dirbančių žemės ūkyje asmenų skaičius (3 pav.).

Tenka gyventojụ 100 ha žemès ūkio paskirties žemès ploto / Population per 100 ha of agricultural land

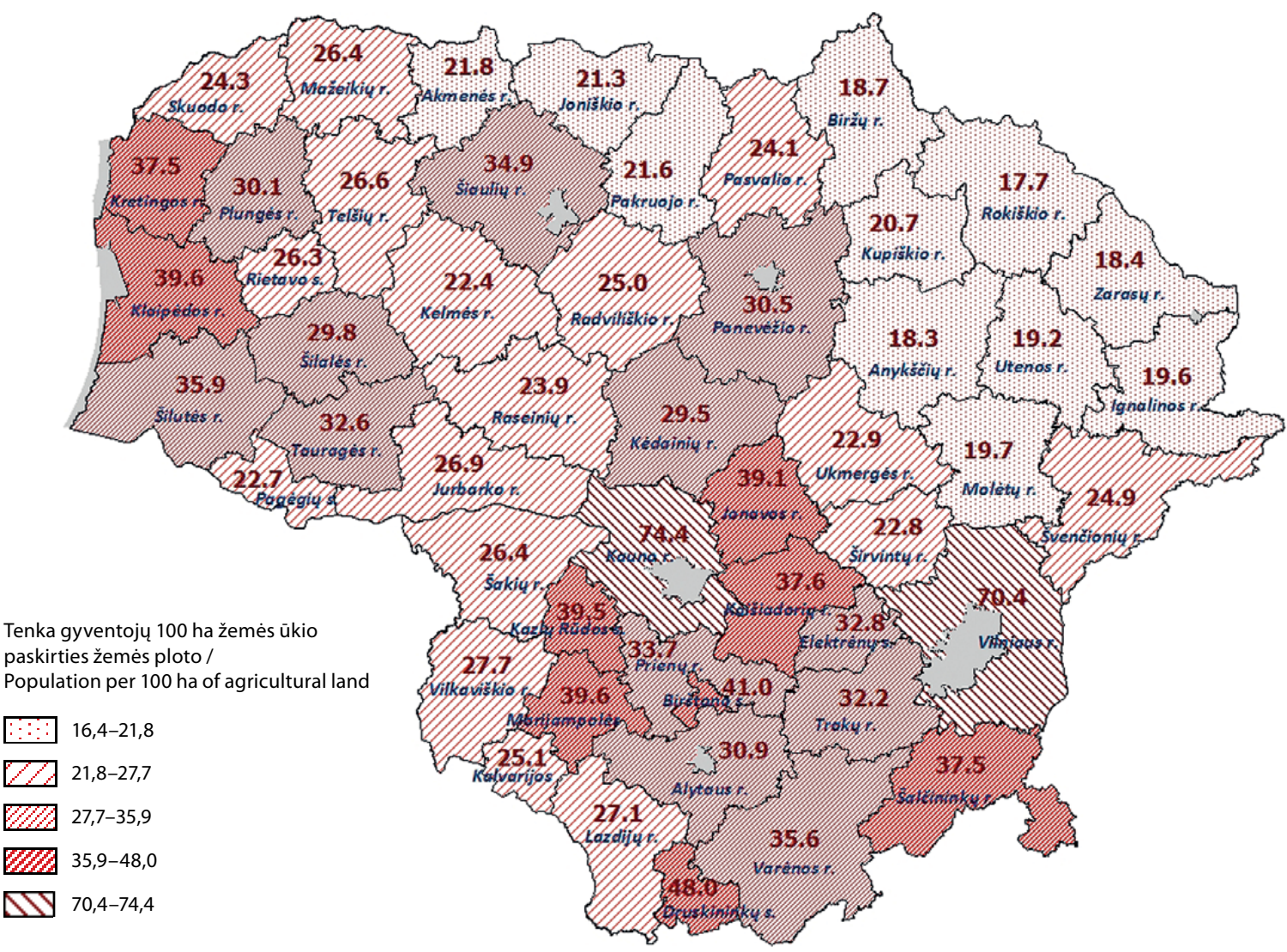

1 pav. Kaimo gyventojų tankumas $2001 \mathrm{~m}$.

Fig. 1. Density of rural population in 2001

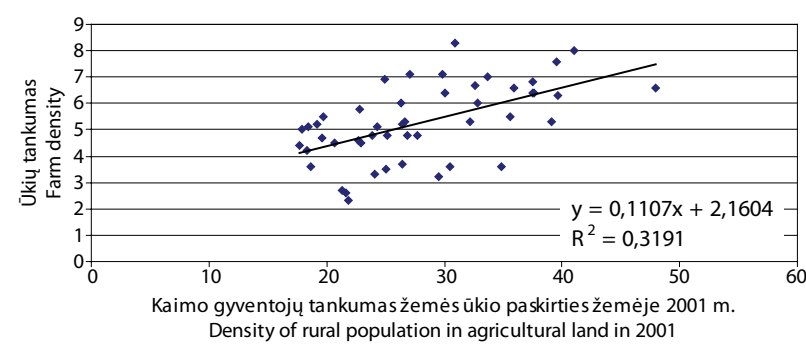

2 pav. Ūkiụ tankumo (ūkiụ, naudojančių daugiau kaip 1 ha žemès ūkio naudmenu, skaičiaus 100 ha žemès ūkio paskirties žemès ploto 2010 m.) priklausomybè nuo kaimo gyventoju tankumo $\left(\mathrm{X}_{1}\right)$ - gyventojų skaičiaus, tenkančio 100 ha žemès ūkio paskirties žemès ploto (2001 m.)

Fig. 2. Dependence of farm density (households using more than 1 ha of agricultural land per 100 ha of agricultural land in 2010) on the rural population density $\left(X_{1}\right)$ - population per 100 hectares of agricultural land (2001)

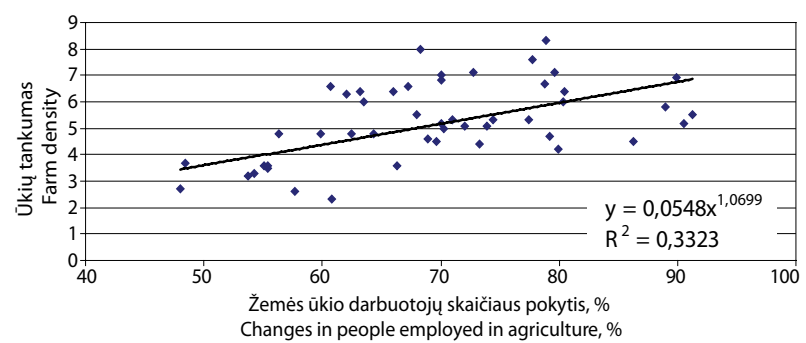

3 pav. Ūkių tankumo (ūkių, naudojančių daugiau kaip 1 ha žemès ūkio naudmenu, skaičiaus 100 ha žemès ūkio paskirties žemės ploto $2010 \mathrm{~m}$.) priklausomybė nuo $\mathrm{X}_{2}$ - žemės ūkyje užimtų darbuotojų skaičiaus pokyčių \% per 2003-2010 m. laikotarpi

Fig. 3. Dependence of farm density (households using more than 1 ha of agricultural land per 100 ha of agricultural land in 2010) on $X_{2}$ - changes in \% of people employed in agriculture over 2003-2010 
3. Ūkių tankumo (Y) ir šeimų, laikančių galvijus, skaičiaus pokyčių per 2003-2010 m. laikotarpi ( $\left.\mathbf{X}_{3}\right)$ : ploto vienetui tenkantis ūkių skaičius santykinai didesnis tose savivaldybèse, kuriose lèčiau mažèjo karves ir galvijų prieauglị laikančių ūkių skaičius (4 pav.). Analogiška priklausomybė nustatyta ir tarp ūkių tankumo bei kiaules laikančių šeimų skaičiaus pokyčių $\left(\mathrm{R}^{2}=0,082\right)$.

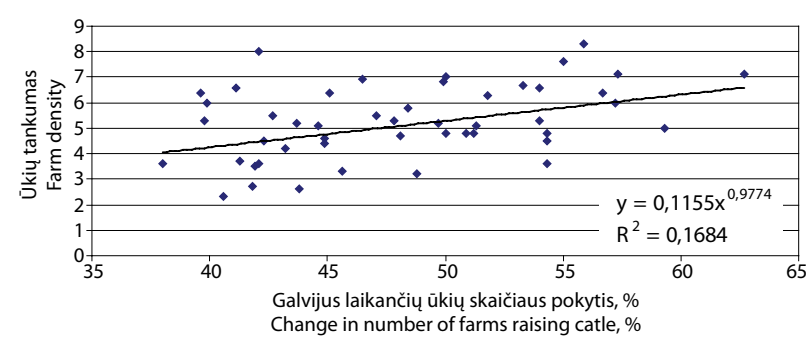

4 pav. Ūkių tankumo (ūkių, naudojančių daugiau kaip 1 ha žemės ūkio naudmenų, skaičiaus 100 ha žemės ūkio paskirties žemès ploto $2010 \mathrm{~m}$.) priklausomybè nuo $\mathrm{X}_{3}$ - galvijus laikančių ūkių skaičiaus pokyčių \% per 2003-2010 m. laikotarpi

Fig. 4. Dependence of farm density (households using more than 1 ha of agricultural land per 100 ha of agricultural land in 2010) on $X_{3}$ - change in $\%$ of number of farms raising cattle over 2003-2010

Pagal atliktos analizès duomenis nagrinètų veiksnių ịtaką ūkių išsidèstymo tankumui galima išreikšti šia daugianare lygtimi:

$$
Y=-6,39+0,137 X_{1}+0,0736 X_{2}+0,056 X_{3} \text {, }
$$

čia $\mathrm{Y}$ - žemès ūkio gamyba užsiimančių ūkių tankumas, išreikštas ūkių skaičiumi ploto vienetui; $\mathrm{X}_{1}$ - kaimo gyventojų tankumas; $\mathrm{X}_{2}$ - žemès ūkio veiklą vykdančių darbuotojų skaičiaus pokyčių intensyvumas; $\mathrm{X}_{3}$ - galvijus laikančių ūkių skaičiaus pokyčių intensyvumas.

Daugianarès koreliacijos koeficientas $r=0,8816$, determinacijos koeficientas $R^{2}=0,7772$, esant patikimumo lygmeniui $t>2$ (99\%). Likusius $22 \%$ lemia kiti tyrimuose neišnagrinèti veiksniai.

Išanalizavus nustatytas ryšys tarp ūkių skaičiaus ir kaimo gyventojų skaičiaus mažéjimo. Pvz., porinès koreliacijos lygtyje determinacijos koeficientas tarp ūkių skaičiaus ir visų kaimo gyventojų skaičiaus pokyčių $\mathrm{R}^{2}=0,1423$. Tai reiškia, kad mažejant kaimo gyventojų skaičiui analogiškai mažeja ir žemès ūkio veikla užsiimančių ūkiu skaičius. Per 2003-2010 m. laikotarpi vidutiniškai kasmet ūkiu skaičius mažèjo po 10,3 tūkst. Per 2007-2013 m. laikotarpi žemès ūkio naudmenas ir pasėlius deklaruojančių ūkių skaičius vidutiniškai kasmet mažèjo po 8,0 tūkst. (2013 m. jų buvo 146,8 tūkst.). Todèl ūkių skaičiaus mažèjimą le- miančių priežasčių pašalinimas gali turèti teigiamos itakos išsaugant kaimo gyventojų, žemės ūkyje dirbančių asmenų ir gyvulius laikančių šeimų skaičių bei didinant žemès ūkio gamybos intensyvumą. Viena iš priemonių, stabilizuojančių kaimo gyventojų skaičių yra urbanistinio karkaso sistemos pletojimas kaimo vietovèse, atsižvelgiant įžemès ūkio plètros poreikius. Šiam tikslui atlikti stambiujų kaimo gyvenamųjų vietovių (miestelių ir daugiau kaip 100 gyventojų turinčiu kaimų) išsidèstymo ir pokyčiu tyrimai.

\section{Gyvenamųjų vietovių klasifikacija}

2013 m. Lietuvoje buvo 103 miestai, iš jų 101 turintis aptarnaujamas agrarines teritorijas. Miestai yra kompaktiškai užstatytos gyvenamosios vietovès, turinčios daugiau kaip 3000 gyventojų, iš kurių daugiau kaip 2/3 dirbančiụjų dirba pramonès, verslo bei gamybinès ir socialinès infrastruktūros srityse. Miestų statusą igijo ir buvusios miesto tipo gyvenvietès, todèl $2013 \mathrm{~m}$. šalyje net 39 miestuose yra mažiau kaip 3000 gyventojų. Pagal ittaką kaimo apgyvendinimo sistemai bei pagal dydi miestus galima suskirstyti taip:

- miestai-administracinių vienetų centrai. Iš jų 5 miestai yra regionų ir apskričių bei savivaldybių centrai, kiti 5 miestai - apskričių bei savivaldybių centrai, o 41 miestas turi tik savivaldybių centrų funkcijas;

- kiti miestai, iš jų 20 miestų, yra stambesni kaip 2 tūkst. gyventojų, o 31 mieste gyventojų skaičius yra mažiau kaip 2 tūkst. žmonių. Iš jų mažiausi: Panemunè (265 gyventojai), Troškūnai (431 gyventojas), taip pat Smalininkai, Kavarskas, Užventis, Dusetos, Pandèlys ir Dūkštas (mažiau nei 1 tūkst. gyventojų). Vidutinis gyventojų skaičius II grupès mieste $2013 \mathrm{~m}$. buvo 2,7 tūkst. žmonių.

Mažiesiems miestams pagal kaimo gyventojų aptarnavimo funkcijas prilygsta kaimo gyvenamosios vietovès - miesteliai. Miestelis - tai kompaktiškai užstatyta gyvenvieté, turinti 500-3000 gyventojų, iš kurių daugiau kaip puse dirbančiųjų dirba pramonès, verslo bei gamybinès ir socialinès infrastruktūros srityse, taip pat jiems priskiriami tradiciniai miesteliai. Pagal ši ịstatymu nustatytą apibrèžimą galima teigti, jog $2011 \mathrm{~m}$. Lietuvoje buvo 240 tradicinių miestelių, 85 iš stambių kaimų naujai išaugę miesteliai, esantys stambiųjų miestų itakos zonose, ir 138 kiti, atokiau esantys, naujai išaugę miesteliai (iš viso - 463 miesteliai). Likusias gyvenamąsias vietoves sudaro kaimai istoriškai susiformavę teritoriniai vienetai su gyvenviete, kuri mažesnè už miestą ir paprastai nèra didesnè nei 5 tūkst. gyventojų. Šiuose tyrimuose smulkiesiems 
kaimams priskirti ir viensèdžiai - istoriškai susiformavusios gyvenamosios vietovės, paprastai sudarytos arba kilusios iš vienos sodybos ir turinčios ne daugiau kaip 20 objektų skirtingu adresu ${ }^{1}$.

Miestai su miesteliais sudaro urbanistinị karkasą, kurio perspektyvas sprendžia visoms administracinių vienetų teritorijoms parengti bendrieji planai. Atliekant stambiujju kaimo gyvenamuju vietovių tyrimus, jos santykinai suskirstytos $\mathbf{6} 6$ grupes priklausomai nuo gyvenvietès dydžio ir jų išsidèstymo miestų bei miestelių atžvilgiu (stambiosioms kaimo gyvenvietèms priskirti miesteliai, taip pat kaimai, kuriuose $2001 \mathrm{~m}$. arba 2011 m. gyveno daugiau kaip 100 gyventojų). Tai:

A kategorija - priemiesčių gyvenvietès, esančios arti I grupès miestų. Joms priskirti miesteliai ir stambieji kaimai, esantys iki $5 \mathrm{~km}$ atstumu nuo Vilniaus, Kauno ir Klaipedos miestų ribos ir iki 2-3 km atstumu nuo miestų-savivaldybių centrų ribos. Šios gyvenvietės dažniausiai naudojasi miestų infrastruktūra ir gyventojų aptarnavimo įstaigomis, jos pasižymi didžiausiu užstatymo intensyvumu, tačiau jose gyvenančių žmonių veikla paprastai yra mažiau susijusi su žemès ūkiu. Iš viso šalyje yra 378 priemiesčiu gyvenvietės, iš jų stambiausios (skliausteliuose - gyventoju skaičius 2011 m.): Gudiena (1563), Domeikava (5006), Karmèlava II (1585), Ramučiai (2372), Neveronys (2998), Raudondvaris (4142), Ringaudai (2861), Šlienava (1987), Dembava (2450), Ginkūnai (2877), Jašiūnai (1565), Avižieniai (2125), Juodšiliai (1744), Valčiūnai (1874), Kalveliai (1592), Nemèžis (2498), Skaidiškès (4133), Pagiriai (3451), Didžioji Riešè (2520), Rudamina (3981), Zujūnai (1660). Vidutinis priemiesčio gyvenvietès dydis $2011 \mathrm{~m}$. buvo 461 gyventojas;

B kategorija - miesteliai. Iš viso šalyje yra 378 miesteliai, nepriskirti priemiesčių gyvenviečių kategorijai. Pažymètina, kad 13 tradicinių miestelių yra sunykę ir šiuo metu nebeatlieka miesteliams būdingų socialinių ar ekonominių funkcijų. Tai Lyduvenai (99), Palèvenè (74), Žemoji Panemunè (64), Gadūnavas (98), Labanoras (59), Truskava (129), Subačius (149), Keturvalakiai (113), Žalpiai (106), Lauko Soda (134), Zibalai (129), Lyduokiai (142) ir Šešuoliai (138). Dar 51 tradiciniame miestelyje gyvena 151-300 gyventojų, 57-iuose miesteliuose 301-500 gyventojų. Dauguma miestelių buvo parinkti ir ugdomi kaip lokaliniai gyventojus ir gamybą aptarnaujantys centrai - ūkių centrinès gyvenvietès. Stambiausi miesteliai yra išaugę iki 1,5-2,0 tūkst. ir daugiau gyventojų. Tai Leipalingis (1552), Rukla (2098), Rumšiškès (1651), Akademija (2807), Babtai (1563), Viduklè (1678), Pilviškiai (2305), Švèkšna (1649), Vèžaičiai (1646),

\footnotetext{
1 LR teritorijos administracinių vienetų ir jų ribų ịstatymas, $1994 \mathrm{~m}$.
}

Krekenava (1636), Baisogala (2034), Kairiai (1850), Kvèdarna (1597), Tirkšliai (1503), Maišiagala (1636). Vidutinis miestelio dydis - 598 gyventojai;

C kategorija - stambieji priemiesčių kaimai, esantys iki 1-2 $\mathrm{km}$ atstumu nuo miestelių bei II grupès miestų. Tokių kaimų yra 304, vidutiniškai viename kaime gyvena 220 žmonių. Savo dydžiu jie neprilygsta A kategorijos (priemiesčių) gyvenvietėms, tačiau padidina gretimai esančio miesto ar miestelio urbanizuotos teritorijos plotą bei gyventojų skaičių;

D kategorija - kiti atokiau esantys stambūs kaimai, kurie, be priemiesčiu gyvenviečių ir miestelių, buvo plètojami kaip buvusių kolūkių ir valstybinių ūkių centrinès gyvenvietès. Tokių kaimų yra 617, vidutinis kaimo dydis - 256 gyventojai. Racionalaus dydžio ūkių, kaip teritorinių gamybinių vienetų, kūrimas leido suformuoti palyginti tolygiai išsidèsčiusių gyvenviečiu tinklą; jos papildẻ lokalinių centrų vykdomas gyventojų aptarnavimo funkcijas, sudarè galimybę stabilizuoti kaimo gyventojų skaičių: išsikeliančios iš senų vienkiemių bei naujai atsikèlusių žemès ūkio specialistų šeimos kūrèsi ne miestuose, o centrinèse ūkių gyvenvietèse;

E kategorija - kiti stambūs kaimai, vystyti ir išaugę kaip žemès ūkio įmonių gamybinių padalinių centrai ar, esant poreikiui, skirti pramonès įmonėms aptarnauti, miškų ūkio veiklai ir kt. (pagalbinès ir neplèstinos gyvenvietès). Tokių kaimų yra 830, vidutinis kaimo dydis - 147 gyventojai.

Kitų, smulkiųjų, kaimų (įskaitant viensèdžius), arba nepriskirtų jokiai kategorijai gyvenamųjų vietovių, kuriose buvo bent vienas gyventojas, skaičius 2011 m. - 14,3 tūkst. Lyginant su 2001 m. duomenimis, per 10 metų jų skaičius sumažèjo 1626. Pažymètina, kad stambiosiose gyvenvietèse $2011 \mathrm{~m}$. gyveno $74,5 \%$ visų kaimo gyventojų, o gyventojų mažejjimas intensyvesnis tik smulkiose kaimo gyvenamosiose vietovèse (1 lentelè).

Iš viso Lietuvoje $2011 \mathrm{~m}$. buvo 2507 kaimo gyvenamosios vietoves, kuriose $2001 \mathrm{~m}$. arba $2011 \mathrm{~m}$. gyveno daugiau nei 100 gyventojų. Pagal dydị jos pasiskirstè taip: stambesnès nei 1000 gyventojų - 86, 751-1000 gyventojų - 77, 501-750 gyventojų - 172, 301-500 gyventojų - 433, 151-300 gyventojų - 838, iki 150 gyventojų - 901. Iš jų 337 gyvenvietès (daugiausia - arti stambiųjų miestų) per 2001-2011 m. laikotarpị išaugo iki 100 gyventojų, o 114 gyvenviečių liko mažiau nei 100 gyventojų.

Vien atskirai išsidèsčiusių miestų, miestelių bei stambiųjų kaimų skaičius Lietuvoje - 1926. Stambiosiose kaimo gyvenamosiose vietovèse pastebimas santykinai lètesnis gyventojų skaičiaus mažèjimas nei likusiuose kaimuose, o Vilniaus, Kauno ir Klaipedos rajonuose esančiose stambiosiose gyvenvietèse jų skaičius netgi didèja (2 lentelè). 
1 lentelè. Gyventojų skaičiaus pokyčiai Lietuvos kaimo gyvenamosiose vietovèse

Table 1. Changes in number of population in Lithuanian rural residential places

\begin{tabular}{|c|c|c|c|c|c|c|c|}
\hline \multirow[t]{2}{*}{ Rodikliai / Indices } & \multicolumn{3}{|c|}{$\begin{array}{l}\text { Kaimo gyventoju skaičius, tūkst. / } \\
\text { Rural population, } \\
\text { in thousands }\end{array}$} & \multicolumn{2}{|c|}{$\begin{array}{c}\text { Pokyčiai } \\
\text { per 1989-2001 m. / } \\
\text { Changes } \\
\text { over 1989-2001 }\end{array}$} & \multicolumn{2}{|c|}{$\begin{array}{c}\text { Pokyčiai } \\
\text { per 2001-2011 m. } \\
\text { Changes } \\
\text { over 2001-2011 }\end{array}$} \\
\hline & $\begin{array}{l}1989 \mathrm{~m} . / \\
\text { year }\end{array}$ & $\begin{array}{l}2001 \mathrm{~m} . / \\
\text { year }\end{array}$ & $\begin{array}{l}2011 \mathrm{~m} . / \\
\text { year }\end{array}$ & $\begin{array}{l}\text { tūkst. / } \\
\text { thousands }\end{array}$ & $\%$ & $\begin{array}{l}\text { tūkst. / } \\
\text { thousands }\end{array}$ & $\%$ \\
\hline $\begin{array}{l}\text { Priemiesčiu kaimo gyvenvietės prie } \\
\text { stambiųjų miestų ir savivaldybių centru (A) / } \\
\text { Suburban villages near major towns and } \\
\text { municipal centers (A) }\end{array}$ & 146,7 & 164,4 & 174,2 & $+17,7$ & $+12,1$ & $+9,8$ & $+6,0$ \\
\hline $\begin{array}{l}\text { Atskirai išsidėstę miesteliai ir stambieji } \\
\text { priemiesčių kaimai, esantys prie mažesnių } \\
\text { miestu ir prie miestelių }(B+C) / \\
\text { Separately located small towns and large } \\
\text { suburban villages near smaller cities } \\
\text { and towns }(B+C)\end{array}$ & 342,3 & 330,6 & 287,8 & $-11,7$ & $-3,4$ & $-42,8$ & $-12,9$ \\
\hline $\begin{array}{l}\text { Kiti atskirai išsidèstę stambūs kaimai (D+E) / } \\
\text { Other large villages located separately (D+E) }\end{array}$ & 318,9 & 323,9 & 279,9 & $+5,0$ & $+1,6$ & $-44,0$ & $-13,6$ \\
\hline $\begin{array}{l}\text { Kiti, smulkieji, kaimai ir viensèdžiai } \\
\text { (jokiai kategorijai nepriskirtos kaimo } \\
\text { gyvenamosios vietovès) / } \\
\text { Other small villages and farmsteads } \\
\text { (nonecategorized rural residential areas) }\end{array}$ & 380,1 & 332,8 & 271,9 & $-47,3$ & $-12,4$ & $-60,9$ & $-18,3$ \\
\hline Iš viso / Total & 1188,0 & 1151,7 & 1013,8 & $-36,3$ & $-3,1$ & $-137,9$ & $-12,0$ \\
\hline
\end{tabular}

2 lentelè. Kaimo gyventojams paslaugas teikiančių stambiųjų gyvenamųjų vietovių analizė

Table 2. Analysis of large residential areas serving rural residents

\begin{tabular}{|c|c|c|c|c|c|c|c|c|}
\hline \multirow{2}{*}{$\begin{array}{l}\text { Apskritis, rajonas } \\
\text { (savivaldybè) / } \\
\text { County, district } \\
\text { (municipality) }\end{array}$} & \multicolumn{2}{|c|}{$\begin{array}{l}\text { Priemiesčių stambiosios } \\
\text { kaimo gyvenamosios } \\
\text { vietovės / } \\
\text { Existing large-scale } \\
\text { rural suburban } \\
\text { residential areas }\end{array}$} & \multicolumn{3}{|c|}{$\begin{array}{l}\text { Atskirai išsidèsčiusios stambiosios } \\
\text { gyvenamosios vietovès } \\
\text { (be priemiestinių) / } \\
\text { Separately located large } \\
\text { residential areas (without } \\
\text { suburban areas) }\end{array}$} & \multirow{2}{*}{$\begin{array}{c}2011 \mathrm{~m} . \\
\text { gyveno } \\
\text { stambio- } \\
\text { siose } \\
\text { kaimo } \\
\text { gyvenvie- } \\
\text { tėse, \% / } \\
\text { Residents } \\
\text { who lived } \\
\text { in large } \\
\text { rural } \\
\text { areas in } \\
2011 \% \%\end{array}$} & \multicolumn{2}{|c|}{$\begin{array}{l}\text { Kaimo gyventojų skaičiaus } \\
\text { pokyčiai per 2001-2011 m. } \\
\text { laikotarpi, \% / } \\
\text { Changes in number of rural } \\
\text { population during year } \\
\text { 2001-2011, \% }\end{array}$} \\
\hline & $\begin{array}{l}\text { esančios } \\
\text { prie miestų- } \\
\text { savivaldybių } \\
\text { centrų / near } \\
\text { cities and } \\
\text { municipal } \\
\text { centers }\end{array}$ & $\begin{array}{l}\text { esančios } \\
\text { prie kitų } \\
\text { miestų ir } \\
\text { miestelių / } \\
\text { near other } \\
\text { cities and } \\
\text { towns }\end{array}$ & $\begin{array}{l}\text { miestai } \\
\text { ir mies- } \\
\text { teliai / } \\
\text { cities } \\
\text { and } \\
\text { towns }\end{array}$ & $\begin{array}{c}\text { kitos kaimo } \\
\text { gyvenvietès } \\
\text { (be priemiesčių } \\
\text { gyvenviečių) / } \\
\text { other villages } \\
\text { (without } \\
\text { suburban } \\
\text { areas }\end{array}$ & $\begin{array}{l}\text { iš viso / } \\
\text { total }\end{array}$ & & $\begin{array}{c}\text { stambiosiose } \\
\text { gyvenvietėse / } \\
\text { in large settle- } \\
\text { ments }\end{array}$ & $\begin{array}{c}\text { kituose kai- } \\
\text { muose } \\
\text { (iskaitant } \\
\text { viensèdžius) / } \\
\text { in other villa- } \\
\text { ges (including } \\
\text { farmsteads) }\end{array}$ \\
\hline $\begin{array}{l}\text { Alytaus apskritis / } \\
\text { Alytus county }\end{array}$ & 22 & 29 & 26 & 125 & 151 & 71,8 & $-11,9$ & $-22,6$ \\
\hline $\begin{array}{l}\text { Kauno apskritis / } \\
\text { Kaunas county }\end{array}$ & 68 & 46 & 68 & 214 & 282 & 79,3 & $-5,1$ & $-8,1$ \\
\hline $\begin{array}{l}\text { Klaipėdos apskritis / } \\
\text { Klaipėda county }\end{array}$ & 31 & 38 & 48 & 128 & 176 & 81,8 & $-3,0$ & $-16,9$ \\
\hline $\begin{array}{l}\text { Marijampolès apskritis / } \\
\text { Marijampolès county }\end{array}$ & 23 & 23 & 41 & 142 & 183 & 76,0 & $-12,7$ & $-19,6$ \\
\hline $\begin{array}{l}\text { Panevėžio apskritis / } \\
\text { Panevėžys county }\end{array}$ & 30 & 28 & 66 & 142 & 208 & 70,5 & $-15,8$ & $-11,1$ \\
\hline $\begin{array}{l}\text { Šiaulių apskritis / } \\
\text { Šiauliai county }\end{array}$ & 42 & 39 & 54 & 196 & 250 & 76,5 & $-15,9$ & $-26,4$ \\
\hline $\begin{array}{l}\text { Tauragès apskritis / } \\
\text { Tauragè county }\end{array}$ & 21 & 24 & 36 & 103 & 139 & 71,1 & $-16,4$ & $-24,5$ \\
\hline $\begin{array}{l}\text { Telšių apskritis / } \\
\text { Telšiai county }\end{array}$ & 33 & 13 & 35 & 92 & 127 & 77,6 & $-12,6$ & $-24,4$ \\
\hline
\end{tabular}




\begin{tabular}{|c|c|c|c|c|c|c|c|c|}
\hline \multirow{2}{*}{$\begin{array}{l}\text { Apskritis, rajonas } \\
\text { (savivaldybè) / } \\
\text { County, district } \\
\text { (municipality) }\end{array}$} & \multicolumn{2}{|c|}{$\begin{array}{l}\text { Priemiesčių stambiosios } \\
\text { kaimo gyvenamosios } \\
\text { vietovės / } \\
\text { Existing large-scale } \\
\text { rural suburban } \\
\text { residential areas }\end{array}$} & \multicolumn{3}{|c|}{$\begin{array}{l}\text { Atskirai išsidèsčiusios stambiosios } \\
\text { gyvenamosios vietovės } \\
\text { (be priemiestinių) / } \\
\text { Separately located large } \\
\text { residential areas (without } \\
\text { suburban areas) }\end{array}$} & \multirow{2}{*}{$\begin{array}{l}2011 \mathrm{~m} . \\
\text { gyveno } \\
\text { stambio- } \\
\text { siose } \\
\text { kaimo } \\
\text { gyvenvie- } \\
\text { tèse, \% / } \\
\text { Residents } \\
\text { who lived } \\
\text { in large } \\
\text { rural } \\
\text { areas in } \\
2011, \%\end{array}$} & \multicolumn{2}{|c|}{$\begin{array}{l}\text { Kaimo gyventojų skaičiaus } \\
\text { pokyčiai per } 2001-2011 \mathrm{~m} \text {. } \\
\text { laikotarpi, \% / } \\
\text { Changes in number of rural } \\
\text { population during year } \\
\text { 2001-2011, \% }\end{array}$} \\
\hline & $\begin{array}{c}\text { esančios } \\
\text { prie miestų- } \\
\text { savivaldybių } \\
\text { centrų / near } \\
\text { cities and } \\
\text { municipal } \\
\text { centers }\end{array}$ & $\begin{array}{l}\text { esančios } \\
\text { prie kitų } \\
\text { miestų ir } \\
\text { miestelių / } \\
\text { near other } \\
\text { cities and } \\
\text { towns }\end{array}$ & $\begin{array}{l}\text { miestai } \\
\text { ir mies- } \\
\text { teliai / } \\
\text { cities } \\
\text { and } \\
\text { towns }\end{array}$ & $\begin{array}{l}\text { kitos kaimo } \\
\text { gyvenvietės } \\
\text { (be priemiesčių } \\
\text { gyvenviečių) / } \\
\text { other villages } \\
\text { (without } \\
\text { suburban } \\
\text { areas }\end{array}$ & $\begin{array}{l}\text { iš viso / } \\
\text { total }\end{array}$ & & $\begin{array}{c}\text { stambiosiose } \\
\text { gyvenvietėse / } \\
\text { in large settle- } \\
\text { ments }\end{array}$ & $\begin{array}{l}\text { kituose kai- } \\
\text { muose } \\
\text { (jskaitant } \\
\text { viensėdžius) / } \\
\text { in other villa- } \\
\text { ges (including } \\
\text { farmsteads) }\end{array}$ \\
\hline $\begin{array}{l}\text { Utenos apskritis / } \\
\text { Utena county }\end{array}$ & 25 & 21 & 44 & 99 & 143 & 58,9 & $-18,0$ & $-23,6$ \\
\hline $\begin{array}{l}\text { Vilniaus apskritis / } \\
\text { Vilnius county }\end{array}$ & 83 & 43 & 61 & 206 & 267 & 73,1 & $+1,2$ & $-16,1$ \\
\hline $\begin{array}{l}\text { Iš viso Lietuvoje / } \\
\text { Total in Lithuania }\end{array}$ & 378 & 304 & 479 & 1447 & 1926 & 74,5 & $-9,5$ & $-18,6$ \\
\hline \multicolumn{9}{|c|}{ Iš to skaičiaus rajonai prie didžiųjų miestų / Out of it, in districts around bigger cities } \\
\hline $\begin{array}{l}\text { Kauno rajonas / } \\
\text { Kauno district }\end{array}$ & 36 & 16 & 21 & 45 & 66 & 85,9 & $+9,6$ & $+61,7$ \\
\hline $\begin{array}{l}\text { Klaipėdos rajonas / } \\
\text { Klaipėdos district }\end{array}$ & 14 & 18 & 14 & 43 & 57 & 83,0 & $+26,4$ & $-7,1$ \\
\hline $\begin{array}{l}\text { Panevėžio rajonas / } \\
\text { Panevėžio district }\end{array}$ & 13 & 11 & 19 & 34 & 53 & 78,5 & $-7,4$ & $-14,3$ \\
\hline $\begin{array}{l}\text { Šiaulių rajonas / } \\
\text { Šiaulių district }\end{array}$ & 17 & 9 & 11 & 25 & 36 & 81,9 & $-6,8$ & $-34,8$ \\
\hline $\begin{array}{l}\text { Vilniaus rajonas / } \\
\text { Vilniaus district }\end{array}$ & 61 & 18 & 16 & 68 & 84 & 82,7 & $+12,7$ & $-4,9$ \\
\hline
\end{tabular}

Šaltiniai: Vḷ Valstybės žemès fondas archyvas; Statistikos departamentas: 2001-2011 m. gyventoju surašymo duomenys. Sources: State Land Fund, the Department of Statistics: Census data.

\section{Stambiųjų gyvenamųjų vietovių išsidèstymas ir jų perspektyvų planavimas}

Atskirai stambiai gyvenamajai vietovei (jų grupei) tenkantis aptarnaujamos teritorijos plotas dèl buvusio planingo žemés ùkio įmonių centrų vystymo šalies teritorijoje yra gana vienodas; šie gyventojų aptarnavimo centrai rečiau išsidèstę tik didesnius miškų masyvus turinčiose savivaldybèse (5 pav.).

Stambiųjų gyvenviečių tinklui išsaugoti ypač svarbu tinkamas urbanistinio karkaso planavimas savivaldybių teritorijų bendruosiuose planuose ir šių planų igyvendinimas. Nesant valstybès ar savivaldybių priemonemis vykdomo gyvenamosios statybos ir infrastruktūros plètros reguliavimo mechanizmo, galimi žymūs kaimo apgyvendinimo sistemos pokyčiai, tarp jų ir turintys neigiamos įtakos žemès ūkio veiklai. Problemiškiausi yra rajonai, kuriuose sparčiai mažèja kaimo gyventojų skaičius ir yra nedaug stambių gyvenamųjų vietovių. Detaliau išnagrinèjus
Zarasų rajono gyvenamąsias vietoves nustatyta, jog rajone vienos atskirai išsidèsčiusios stambios gyvenvietès aptarnaujama teritorija - 3,7 tūkst. ha žemès ūkio paskirties žemès ploto (Lietuvoje - 2,0 tūkst. ha). Rajone per 1989-2001 m. laikotarpi vidutiniškai per metus išnykdavo (nèra gyventojų, išliko tik kaimo pavadinimas, reikalingas nekilnojamojo turto objekto adresui registruoti) 6 kaimai, 2001-2001 m. laikotarpiu - 10 kaimų (3 lentelè).

Esant dabartinėms tendencijoms iki $2030 \mathrm{~m}$. rajone gali išlikti tik 30 miestelių ir stambesnių kaip 50 gyventojų kaimų, 70 kaimų, turinčių 11-50 gyventojų, 70 kaimų, turinčių 4-10 gyventojų, ir 120 kaimų, turinčių 1-3 gyventojus, - iš viso 370 kaimų, arba $28 \%$ mažiau, nei yra šiuo metu. Bendras kaimo gyventojų skaičius gali sumažèti iki 8-9 žmonių 100 ha žemès ūkio paskirties žemès ploto (šiuo metu vidutiniškai Zarasų rajone yra 14, Lietuvoje - 26). 


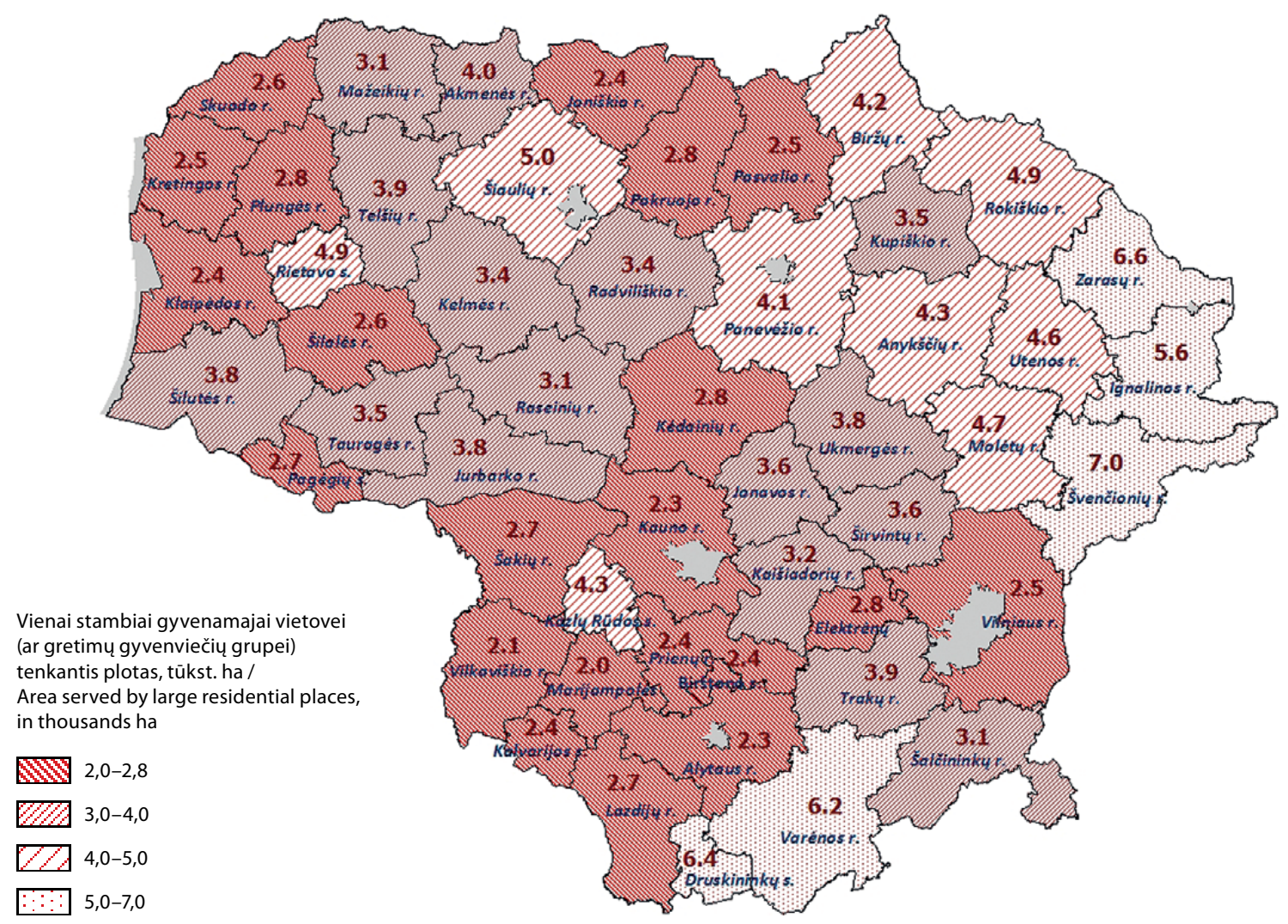

5 pav. Atskirai išsidèsčiusių stambiųjų gyvenamųjų vietovių aptarnaujama teritorija kaimo vietoveje

Fig. 5. Teritory, served by separatly distributed large residental areas

3 lentelè. Kaimu (iskaitant viensèdžius) skaičiaus pokyčiai Zarasų rajone 1989-2011 m. laikotarpiu Table 3. Changes in number of villages (including farmstead) in Zarasai district from 1989 to 2011

\begin{tabular}{|c|c|c|c|c|c|}
\hline \multirow{2}{*}{$\begin{array}{l}\text { Gyventoju skaičius / } \\
\text { Population }\end{array}$} & \multicolumn{3}{|c|}{$\begin{array}{l}\text { Kaimu skaičius / } \\
\text { Number of villages }\end{array}$} & \multicolumn{2}{|c|}{$\begin{array}{l}\text { Pokyčiai 2001-2011 m. / } \\
\text { Changes over 2001-2011 }\end{array}$} \\
\hline & 1989 m. / year & $2001 \mathrm{~m} . /$ year & $2011 \mathrm{~m}$. / year & Kaimai / villages & $\%$ \\
\hline $\begin{array}{l}\text { daugiau kaip } 100 \text { gyventojų / } \\
\text { over } 100 \text { inhabitants }\end{array}$ & 30 & 27 & 22 & -5 & $-18,5$ \\
\hline $\begin{array}{l}51-100 \text { gyventoju / } \\
51-100 \text { inhabitants }\end{array}$ & 15 & 15 & 15 & - & - \\
\hline $\begin{array}{l}21-50 \text { gyventoju / } \\
21-50 \text { inhabitants }\end{array}$ & 66 & 55 & 40 & -15 & $-27,3$ \\
\hline $\begin{array}{l}11-20 \text { gyventoju / } \\
11-20 \text { inhabitants }\end{array}$ & 111 & 96 & 73 & -23 & $-8,8$ \\
\hline $\begin{array}{l}4-10 \text { gyventoju / } \\
4-10 \text { inhabitants }\end{array}$ & 229 & 203 & 183 & -20 & $-9,9$ \\
\hline $\begin{array}{l}2-3 \text { gyventojai / } \\
2-3 \text { inhabitants }\end{array}$ & 169 & 142 & 113 & -29 & $-20,4$ \\
\hline $\begin{array}{l}1 \text { gyventojas / } \\
1 \text { inhabitant }\end{array}$ & 64 & 80 & 68 & -12 & $-15,0$ \\
\hline Iš viso / Total & 684 & 618 & 514 & -104 & $-16,8$ \\
\hline $\begin{array}{l}\text { Be to, kaimai be gyventoju / } \\
\text { In addition, non-populated villages }\end{array}$ & 109 & 175 & 279 & +104 & $+59,4$ \\
\hline
\end{tabular}

Šaltinis: Statistikos departamentas: gyventojų surašymo (1989, 2001, 2011 m.) duomenys.

Source: Department of Statistics. Census data. 
Racionalaus žemės naudojimo požiūriu kaimo gyventojų ir žemès ūkio veikla užsiimančių žmonių skaičiaus mažèjimas turès neigiamą poveikị žemès ūkio gamybai ir kraštovaizdžiui. Tai - medžiais, krūmais ir piktžolemis apaugę buvusios dirbamosios žemès laukai, prastos būklès keliai ir melioracijos grioviai, apleistos sodybos, vietomis naujai atsiradę ar tik sezono metu lankomi pastatai, dažnai nebūdingi gamtiniam kraštovaizdžiui. Siekiant tokiu pasekmių išvengti, Zarasų rajono savivaldybės teritorijos bendrajame plane numatyta sukurti stabilių bei vystytinų kaimo gyvenamųjų vietovių tinklą, kurị sudarytų 30 atskirai išsidèsčiusių gyvenamųjų vietovių ar jų grupių (1,5 karto daugiau, nei šiuo metu yra kaimo gyventojams teikiančių paslaugas centrų). Tai:

- 6 miestai ir miesteliai - vystytini vietiniai centrai. Vidutinis miestelio dydis $2011 \mathrm{~m}$. - 333 gyventojai. Prie šių centrų prisišliejusių 9 kaimų vidutinis dydis - po 242 gyventojus;

- 13 ūkines funkcijas galinčių vykdyti kaimų papildomų vietinių centrų (vidutinis dydis - po 111 gyventojų);

- 11 rekreacines funkcijas galinčių vykdy ti kaimų papildomų vietinių centrų (vidutinis dydis - po 51 gyventoją).

Panašiu principu buvo planuojama vystyti kaimo apgyvendinimo sistemą ir kitose savivaldybèse su palyginti retu stambiųjų gyvenviečių tinklu. Jų bendrųjų planų sprendiniuose numatyti perspektyvūs lokaliniai centrai (savivaldybių urbanistiniai centrai) parinkti vadovaujantis kriterijais, išdèstytais toliau:

- didesnis gyventojų skaičius ir tolygus gyvenviečiu išsidèstymas planuojamoje teritorijoje;

- esamas potencialas: verslo i̇monès ir darbo vietos, mokyklos, prekybos ir buitinio aptarnavimo įstaigos, kiti socialinès infrastruktūros objektai;

- patogi dislokacija kelių ar rekreacinių vietoviu atžvilgiu, gera inžinerinè infrastruktūra.

Vystytini lokaliniai centrai diferencijuojami pagal reikšmingumo lygmenis (kategorijas), juose numatomos galimybès išsaugoti arba plètoti ịstaigas ar įmones, kurios reikalingos teikiant viešąsias paslaugas gyventojams ir ūkio subjektams, arba galètų funkcionuoti kaip verslo paslaugu ar turizmo centrai. Šiuose centruose numatoma sudaryti sąlygas, padidinančias gyvenamosios statybos ir ūkinès veiklos apimtị.

Nepaisant bendruosiuose planuose numatytų urbanistinių centrų ugdymo perspektyvų, atskiruose plotuose toliau mažèja kaimo gyventojų skaičius, išlieka nevienodos šių teritorijų raidos sąlygos lyginant su ekonomiškai išsivysčiusiais regionais. Susidariusių problemų sprendimas galimas tik kompleksiškai derinant teritorijų planavimo klausimus su valstybès pa- ramos priemonemis. Rekomenduotina, jog rengiant ar tikslinant savivaldybių ir vietos lygmens bendruosius planus būtų detaliau išnagrinèjama kaimo gyventojų skaičiaus bei žmonių užimtumo pokyčiai, susiformavusių ūkių veiklos perspektyvų galimybės, žemės ūkio teritorijų tvarkymo (racionalių ūkių žemès valdų formavimo, vietinès reikšmès kelių, gyvenviečiu gatvių, melioracijos įrenginių, kitų techninès infrastruktūros objektų pagerinimo) poreikis. Tai įmanoma atlikti tik kartu su bendruoju planu atskiroms seniūnijoms rengiant žemès ūkio paskirties teritorijoms tvarkyti ir žemès išteklių naudojimui planuoti skirtus specialiuosius planus - kaimo plètros žemètvarkos projektus.

Reikiamų priemonių planavimas bendrojo plano galiojimo laikotarpiui turètų būti siejamas su kiek ịmanoma detalesniu žemès ūkio ir kaimo plètrai skiriamų lèšų administravimu veiklos subjektams. Lietuvos kaimo pletros 2014-2020 m. laikotarpiui programiniuose dokumentuose numatyta, jog vienu iš pagrindinių ES paramos kaimo plètrai tikslų yra didinti visų tipų žemès ùkio veiklos konkurencingumą ir ūkių perspektyvumą, skatinti socialinę įtrauktị, skurdo mažinimą ir ekonominę plètrą kaimo vietovèse (Kaimo... 2014). Padidejjus žemès naudotojų pajamoms iš ùkinès veiklos bei pagerinus techninę ir socialinę infrastruktūrą, kaimų nykimo procesą įmanoma stabilizuoti. Kartu tai leistų išsaugoti našių žemès ūkio naudmenų plotus, užtikrinti intensyvią žemès ūkio gamybą.

Planuojant priemones, reikalingas savivaldybių urbanistinių struktūrų plètrai, prioritetas turètų būti teikiamas miesteliams ir, esant poreikiui, jų tinklą papildantiems kitiems stambiesiems kaimams vystyti; jie turètų būti visų aptarnavimo zonoje esančių kaimų ir viensẻdžių gyventojų traukos centrais. Planuojamų priemonių realizavimo kriterijais turètų būti gyvenamosios ir kitokios statybos apimties didejjimas bei jaunų šeimų ir ūkinę veiklą vykdančių kaimo gyventojų skaičiaus išsaugojimas.

\section{Išvados}

1. Kaimo gyventojų ir žemès ūkio veiklos subjektų ūkių tankumas savivaldybèse priklauso nuo istoriškai susiklosčiusios apgyvendinimo sistemos ir kaimo vietovèje vykstančių ūkinių bei socialinių pokyčių intensyvumo. Mažiausias ūkių tankumas yra tose savivaldybèse, kur dèl šių pokyčių sparčiausiai mažeja žemès ūkyje užimtų darbuotojų skaičius ir galvijus laikančių ūkių skaičius.

2. Stabiliausias kaimo apgyvendinimo sistemos elementas - miesteliai ir stambieji kaimai, kurių dauguma susiformavo kaip buvusių žemès ūkio įmonių administraciniai ir gamybiniai centrai. Tai sudare sąlygas palyginti tolygiam stambiųjų kaimo gyve- 
namųjų vietovių išsidèstymui. Miesteliai ir kaimai, turintys daugiau kaip 100 gyventojų, $2011 \mathrm{~m}$. sudarè $14,9 \%$ visų kaimo gyvenamųjų vietovių, tačiau juose gyveno $74,5 \%$ visų kaimo gyventojų. Vienai atskirai išsidèsčiusiai stambiajai gyvenamajai vietovei (jų grupei) šalyje vidutiniškai tenka 2,0 tūkst. ha žemès ūkio paskirties žemès ploto.

3. Kaimo gyvenamųjų vietovių dydžio pokyčius lėmè jų išsidestymas miestų ir aptarnaujamos teritorijos atžvilgiu. Per 2001-2011 m. laikotarpi gyventojų skaičius stambiuosiuose kaimuose, išsidèsčiusiuose prie miestų-savivaldybių centrų, netgi padidejo, o kitose stambiose kaimo gyvenamosiose vietovèse sumažèjo 12,9-13,6 \%, mažesniuose kaimuose (iskaitant viensèdžius) - $18,3 \%$.

4. Vienu iš valstybės svertų stambiųjų kaimo gyvenamųjų vietovių plètrai reguliuoti yra savivaldybių teritorijų bendrųjų planų sprendiniai ir jų igyvendinimo organizavimas. Šiuose planavimo dokumentuose numatytos parinktų gyventojų socialinio aptarnavimo centrų vystymo perspektyvos, ịskaitant infrastruktūros vystymą bei gyventojų ir verslo poreikius atitinkančias priemones.

5. Stambiųjų kaimo gyvenamųjų vietovių raidos planavimas rengiant bendruosius planus turètų būti sprendžiamas kompleksiškai kartu su agrarinių teritoriju tvarkymo klausimais, nagrinėjamais kaimo pletros žemètvarkos projektuose, ir derinamas su kaimo plètros programos igyvendinimo priemonemis, galimomis realizuoti konkrečiose seniūnijose.

\section{Literatūra}

Aleknavičius P. 2007. Kaimiškujų teritorijų žemès naudojimo problemos, Žemés ūkio mokslai 14(1): 82-90.

Atkočiūnienè, V.; Giedraitis, B. 2013. Žemès ūkio poveikio kaimo vietovių vystymosi stiprinimo modelis, Management Theory and Studies for Rural Business and Infrastructure Development 35(1): 13-22.

Atkočiūnienè, V. Vaišnoraite, V. 2012. Kaimiškụjų vietovių vystymo strateginio proveržio sąlygos: Dargužių kaimo atvejis, Žemés ūkio mokslai 19(3): 180-191.

Baležentis, A. 2011. Kaimo vietovių raida ir modeliai: darnaus vystymo požiūris, Management theory and studies for rural business and infrastructure development 2(26): 9.

Burinskienè, M.; Lazauskaitė, D. 2010. Mažų miestelių, bažnytkaimių, kaimo gyvenviečių perspektyvos, iš IV Lietuvos urbanistinis forumas. Urbanistine drieka: miesto ir kaimo sandūra, 34-39 [interaktyvus], [žiūrèta $2014 \mathrm{~m}$. balandžio 10 d.]. Prieiga per internetą: http://www.saf.ktu.lt/II_puslapiai/Naujienos/2010urbanforum/PDF\%20UF\%20leidinys\%202010.pdf

Čereškevičius, S. 2012. Besitraukiančių miestų fenomenas: erdvinès struktūros pokyčiai, revitalizacijos principai ir vystymo galimybès, iš VI Lietuvos urbanistinis forumas. Šiuolaikiški miestai ir miesteliai: situacija, vystymosi tendencijos, vizija, 24-32 [interaktyvus], [žiūrèta $2014 \mathrm{~m}$. balandžio 10 d.]. Prieiga per internetą: http://www.am.lt/ VI/files/File/Urbanistinis\%20forumas\%20tinklalapiui\%20 WEB.pdf

Dringelis, L. 2013. Lietuvos miestai, miesteliai ir kaimai: jų urbanistinių ir demografinių pokyčių ịtaka šalies kraštovaizdžio erdvinès struktūros savitumui, Journal of Architecture and Urbanism 37(4): 310-323. http://dx.doi.org/10.3846/20 297955.2013.869884

European Charter for Rural Areas. 1996. [Interaktyvus], [žiūrèta $2012 \mathrm{~m}$. lapkričio $5 \mathrm{~d}$.]. Prieiga per internetą: http://assembly.coe.int/ASP/Doc/XrefViewHTML. asp?FileID $=7441$ \&Language $=\mathrm{EN}$

European regional / spatial planning Charter Torremolinos Charter. 1983. [Interaktyvus], [žiūrèta 2012 lapkričio 30 d.]. Prieiga per internetą: http://xesc.cat/ET2050_library/docs/ landuses/policies/1983_European_Planning_Charter.pdf

Jasaitis, J. 2008. Neurbanizuotų teritorijų plètros administravimas poindustrineje visuomenèje, Ekonomika ir vadyba: aktualijos ir perspektyvos 1(10): 47-63.

Jasaitis, J.; Šurkuvienè S. 2006. Neurbanizuotu vietovių šiuolaikinių funkcijų kūrimas, Ekonomika ir vadyba: aktualijos ir perspektyvos 2(7): 85-93.

Kaimo plètros aktualijos 2014-2020 metu laikotarpiu [interaktyvus], [žiūrèta $2014 \mathrm{~m}$. balandžio 9 d.]. Lietuvos Respublikos žemès ūkio ministerija. Prieiga per internetą: http://www. zum.lt/index.php?1292182156

Kasnauskienè, G.; Ambrozaitienè, D.; Svidlerienè, D.; Balandienè, R. 2009. Demografinè statistika Lietuvoje: pokyčiai atkūrus nepriklausomybę, Lietuvos statistikos darbai (48): 31-40.

Kriaučiūnas, E. 2013. Lietuvos kaimo gyvenviečių tinklo kaitos ypatumai 1989-2011 metais, Kaimo raidos kryptys žiniu visuomeneje 1(5): 53-60.

Kriaučiūnas, E.; Ribokas, G. 2012. Šiaulių apskrities retai apgyventų teritorijų pokyčiai ir demografinès raidos ypatumai, Ekonomika ir vadyba: aktualijos ir perspektyvos 3(27): 135-143.

Kuliešis, G.; Pareigienè, L. 2011. Lietuvos regionų depopuliacijos prielaidų tyrimas, Management theory and studies for rural business and infrastructure development 5(29): 116-125.

Lietuvos Respublikos teritorijos bendrasis planas. 2002. Valstybès žinios, Nr. IX-1154.

Morrison, P. S.; Clark, W. A. V. 2011. Internal migration and employment: macro flows and micro motives, Environment and Planning 43: 1948-1964. http://dx.doi.org/10.1068/a43531

Niedomysl, T. 2006. Migration and place attractiveness, in Geografiska regionstudier. Uppsala universitet. $46 \mathrm{p}$.

Pakalnis, M.; Bardauskienè, D. 2012. Žalioji ir rudoji urbanistika, priešprieša ir sąlytis, konformistiniai sprendimai urbanistikoje, iš VI Lietuvos urbanistinis forumas. Šiuolaikiški miestai ir miesteliai: situacija, vystymosi tendencijos, vizija, 8-13 [interaktyvus], [žiūrèta $2014 \mathrm{~m}$. balandžio $10 \mathrm{~d}$.]. Prieiga per internetą: http://www.am.lt/VI/files/File/ Urbanistinis\%20forumas\%20tinklalapiui\%20WEB.pdf

Stambulo deklaracija dèl gyvenviečiu. 1996 [interaktyvus], [žiūrèta $2014 \mathrm{~m}$. balandžio $12 \mathrm{~d}$.]. Prieiga per internetą: http:// www.am.lt/LSP/files/STAMBUL.pdf

Vidickienė, D.; Melnikiené, R. 2008. Paramos teikimo Lietuvos kaimo regionams kriterijų vertinimas, Management theory and studies for rural business and infrastructure development 12(1): 168-174. 


\section{RESEARCH OF CHANGES OF RURAL RESIDENTIAL AREAS IN LITHUANIA}

\section{P. Aleknavičius, M. Aleknavičius, S. Akelaitytė}

Abstract. This paper presents analysis of the statistical census data for municipalities and rural areas, as well as the analysis of general plans for territories of local municipalities. It was discovered, that the decreasing number of agricultural workers and farmers with livestock has influence on density of rural residents and agricultural entities. Large-scale rural settlements are analyzed and grouped according to the location either in suburban, or in separately located settlements including small towns and former central settlements of agricultural enterprises. Analysis of the dynamics of changes in those settlements was also performed. It was discovered that by forming spatial master plans it is possible to regulate the development of rural residential areas. Moreover, it was suggested to choose for development promising localized centers needed for serving agricultural territories and other areas. This would help to preserve productive farmland and to intensify the traditional agricultural activities, especially in problematic areas with rapidly vanishing villages.

Keywords: residential areas, agricultural land, town, village, general plans.

Reference to this paper should be made as follows: Aleknavičius, P.; Aleknavičius, M.; Akelaitytè, S. 2014. Research of changes of rural residential areas in Lithuania, Journal of Architecture and Urbanism 38(2): 161-172.

\section{PRANAS ALEKNAVIČIUS}

Doctor of Social Sciences, professor at Aleksandras Stulginskis University, Institute of Land Use Planning and Geomatic, Studentu g. 11, LT-53361 Akademija, Kaunas distr., Lithuania. E-mail: pranas.aleknavicius@gmail.com.

Doctor (HP) of Social Sciences. In 1964 graduated Lithuanian Academy of Agriculture, engineer of Land Management. Worked at: National Institute of Land Management, The Ministry of Agriculture of the Republic of Lithuania, Aleksandras Stulginskis University. Candidate of Economic Sciences (1983), Doctor of Social Sciences (1993), Associate Professor (1993), Professor (2009).

Research interests: territory planning, land law, land management, land reform, rural development.

\section{MARIUS ALEKNAVIČIUS}

Doctor of Social Sciences (Economics), assoc. prof. at Aleksandras Stulginskis University, Institute of Land Use Planning and Geomatics, Studentu g. 11, LT-53361 Akademija, Kauno r., Lithuania. E-mail:amarius@takas.lt

MSc in Informatics (1995) at Vytautas Magnus University, Kaunas, Diploma in International Business Management (1996) at Vilnius University, International Business School, MSc in Land Management (2000) at Royal Institute of Technology, Stockholm, Doctor of Social Sciences (Economics) (2007) at Gediminas Technical University, Vilnius.

Worked as assoc. researcher in the Lithuanian Institute of Agrarian Economics (2003-2005), lecturer (2008-2010) and assoc. prof. (since 2010) in Aleksandras Stulginskis University. Reserach ineterests: land market development, urban sprawl, land use changes.

\section{SIGITA AKELAITYTE்}

Master of land managemen, at Aleksandras Stulginskis university (institute of Land use, Planning and Geomatic), Studentu g. 11, LT-53361 Akademija, Kaunas distr., Lithuania.

E-mail: sigitakela@yahoo.com.

In 2012 graduated Aleksandras Stulginskis university.

Research interests: territory planning, land management. Worked as territory planner. 